\title{
Low HDL Cholesterol and ABCA1 in Healthy Individuals
}

\section{Abstract}

High density lipoprotein (HDL) is protective against atherosclerosis. Adenosine triphosphate Binding Cassette transporter subfamily A class 1 (ABCA1) mediates the first step of reverse cholesterol transport i.e. efflux of cholesterol and phospholipid to Apolipoprotein A1 (ApoA1) and HDL formation. The present study aimed at analysing ABCA1 gene and protein expression in peripheral blood mononuclear cells (PBMNCs) of healthy individuals with HDL cholesterol (HDL-C) levels below normal as per NCEP criteria. Group 1 included twenty seven healthy subjects with normal HDL-C levels and normal triglyceride levels and Group 2 included twenty eight healthy subjects with low HDL-C but normal triglyceride levels. ABCA1 gene expression was high by $65.0 \%$ while ABCA1 protein was significantly low by $17.5 \%$ of Group 2 as compared to Group 1. Thus up-regulation of ABCA1 protein failed to translate into ABCA1 protein. This implies some defect at translational and post translational level which needs to be further explored.

Keywords: Reverse cholesterol transport; Apolipoprotein A1; Peripheral blood mononuclear cells

Short Communication
Volume 11 Issue 1 - 2018

Hiren N Chheda ${ }^{1}$, VK Shah ${ }^{2}$ Dhananjaya
Saranath ${ }^{3}$ and Kavita Shallia ${ }^{4 *}$
${ }^{1}$ Sir H. N. Medical Research Society, Sir H. N. Reliance
Foundation Hospital and Research Centre, India
${ }^{2}$ Interventional Cardiologist, Department of Cardiology, Sir H.
N. Reliance Foundation Hospital and Research Centre, India
${ }^{3}$ Executive Director-Research Studies and Additional Projects,
Cancer Patients Aid Association, Ex Professor, School of
Science, NMIMS (Deemed-to-be) University, India
${ }^{4}$ Sir H. N. Medical Research Society, Sir H. N. Reliance
Foundation Hospital and Research Centre, India

*Corresponding author: Kavita Shalia, Sr. Scientist, Sir H. N.
Medical Research Society, Court House, L. T. Road, Mumbai
400 002, India, Tel: +91 022 35493883;
Email: kavita.shalia@ @rfhospital.org
Received: December 22, 2017 | Published: February 20,
2018

Abbreviations: HDL: High Density Lipoprotein; ABCA1: Adenosine Tri-Phosphate Binding Cassette Transporter Subfamily A Class 1; Apo A1: Apolipoprotein A1; HDL-C: HDL Cholesterol; CAD: Coronary Artery Disease; PBMNCs: Peripheral Blood Mononuclear Cells

\section{Introduction}

Peripheral cells obtain their cholesterol from combination of synthesis and uptake from low density lipoproteins (LDL). Most peripheral cells are not able to catabolize cholesterol but transport excess cholesterol from peripheral tissues back to liver, the process called "reverse cholesterol transport" (RCT). This is the only way by which cholesterol homeostasis is maintained in vivo The first step of RCT is uptake of cellular cholesterol by the high density lipoprotein (HDL). A key regulator of this uptake is ATP-Binding Cassette transporter A1 (ABCA1) [1,2]. It mediates the cellular efflux of phospholipid and cholesterol across cell membranes to lipid-poor Apolipoprotein A1 (ApoA1), the major Apo in HDL. Thus it plays a significant role in HDL metabolism and lipid clearance thereby decreasing the risk of atherosclerosis $[3,4]$. ABCA1 mRNA is expressed in leukocytes and macrophages, besides placenta, liver lung and adrenal gland [5].

Insufficient cholesterol efflux may be a consequence of inadequate movement of intracellular cholesterol, too low HDL concentration in the extracellular fluid or impaired ability of these particles to accept cholesterol. The function of ABCA1 as a key regulator of HDL became apparent in 1999 when loss of ABCA1 gene function was determined to be the cause of Tangier's disease who exhibited extremely low levels of HDL-cholesterol (HDL-C) and increased incidences of premature coronary artery disease (CAD) [6-8]. Inadequate transport of cholesterol and phospholipids out of cells leads to accumulation of intracellular sterol and the subsequent development of foam cells, a hallmark of atherosclerotic plaque [9]. Studies with ABCA1 transgenic and knock-out mice have indicated association of overexpression with high HDL-C levels and deletion with atherosclerosis [10-12].

HDL imparts anti-oxidative, anti-inflammatory, and antithrombotic functions $[13,14]$. In the last few decades studies have shown that a low level of HDL-C is a powerful and independent risk factor for CAD even with a normal total plasma cholesterol levels [15-17]. As ABCA1 is critical in HDL formation, the present study was carried out to analyse the expression of ABCA1 gene of peripheral blood mononuclear cells (PBMNCs) at mRNA and protein levels in healthy individuals with low HDL-C.

The study population included healthy individuals with systolic blood pressure/diastolic blood pressure $(\mathrm{SBP} / \mathrm{DBP})=$ $135 / 85 \mathrm{mmHg}$ or less, with normal ECG and carotid Doppler, with no risk factors of CAD (except alchol consumption), triglyceride levels $<200 \mathrm{mg} / \mathrm{dl}$, not on any lipid lowering drug or clinical symptoms of any other organic disease. Their blood sample was collected after overnight twelve hour fast. Those subjects with fasting glucose levels $>110 \mathrm{mg} / \mathrm{dl}$, serum transaminases, Blood Urea Nitrogen, Creatinine levels, lipid profile and complete blood count beyond normal range or abnormal ECGs or Carotid Doppler, were excluded. As per the selection criteria in each group, subjects were recruited in study only after obtaining their informed consent. Information regarding their demographic status, clinical history, family history and medications if any were noted down in detail. The ethical committee of Sir H. N. 
Hospital and Research Centre approved the study protocol. These subjects were further divided into two groups. In Group 1 healthy individuals with normal HDL-C levels were included and in Group 2 healthy individuals with low HDL-C levels were included (Males $<40 \mathrm{mg} / \mathrm{dl}$ or $1.0 \mathrm{mmol} / \mathrm{L}$ and females $<50 \mathrm{mg} / \mathrm{dl}$ or $1.3 \mathrm{mmol} / \mathrm{L}$ ) as per NCEP criteria [18]. In Group 1 five out of 27 and in Group 2 six out of 28 were consuming alcohol occasionally. The details of ABCA1 Gene Expression analysis by Quantitative Real-Time PCR using Taqman Assay and ABCA1 Protein estimation by Enzyme Linked Immunoabsorbent Assay (ELISA) has been described elsewhere [19]. The expression of ABCA1 mRNA was quantitated using comparative Ct method as described in PE User Bulletin 2 and calculated as $2^{\text {-delta delta }} \mathrm{Ct}$. The $\mathrm{Ct}$ value being a numerical value, the change of ABCA1 mRNA transcript (gene expression) of Group 2 is unit less and expressed as percentage relative to that of Group 1. ABCA1 protein is expressed as OD at $450 \mathrm{~nm}$ of $50 \mu \mathrm{g} /$ $\mathrm{ml}$ of total cell protein extract. Results are expressed as mean \pm SD for parametric variables and median and quartiles for nonparametric data variable. The anlaysis of significance of difference between two groups was performed by student's Unpaired ' $t$ '- test. Bivariate correlations were evaluated by Pearson correlation. A p value $<0.05$ was considered statistical significant. Analyses were performed using statistical software SPSS (version 21.0, Chicago, IL).

The demographic and biochemical data is depicted in Table 1. Group 1 and 2 subjects were age and BMI matched. Total cholesterol (TC) levels in Group 2 were marginally less by $12.3 \%$ $(\mathrm{p}<0.01)$ while HDL-C levels $(35.7 \%, \mathrm{p}<0.001)$ were significantly low with TC to HDL Cholesterol ratio $(34.2 \%, \mathrm{p}<0.001)$ and LDLcholesterol (LDL-C) to HDL-C ratio $(40.6 \%, \mathrm{p}<0.001)$ high as compared to Group 1. Significant low levels of Apolipoprotein A1 (Apo A1) $(20.7 \%, \mathrm{p}<0.001)$ and high in $\mathrm{ApoB} / \mathrm{A} 1$ ratio $(22.3 \%$, $\mathrm{p}<0.05$ ) were also observed in Group 2 as compared to Group 1. LDL-C and triglyceride levels were not significantly different between two groups. ABCA1 gene expression of Group 2 was compared against age, gender and BMI matched individuals of Group 1. The ABCA1 gene expression of Group 2 was more by $65 \%$ then Group 1 (Figure 1). The mean absorbance of ABCA1 protein of Group 2 was significantly low by $17.5 \%(\mathrm{p}<0.0001)$ as compared to healthy individuals with normal HDL-C level (Group 1) (Table 2). Pearson correlation (r) analysis of overall data demonstrated significant positive correlation of ABCA1 Protein with HDL-C ( $\mathrm{r}=0.393, \mathrm{p}=0.003)$ and Apo A1 (0.401, $\mathrm{p}=0.002)$ while negative correlation with LDL-C/HDL-C $(r=-0.350, p=0.009)$ and TC/ HDL-C ( $\mathrm{r}=-0.342, \mathrm{p}=0.011)$.

Considering the roles played by HDL in preventing atherosclerosis and thrombosis, there is always curiosity to know the basal status of ABCA1 gene and protein expression in association with peripheral HDL-C levels. A report by Guan et al did demonstrate increased mRNA expression of ABCA1 in circulating mononuclear cells stimulated by simvastatin and in turn improvement in RCT [20]. Albrecht et al explored the role of leukocyte ABCA1 gene expression and indices of glycemia in normal and diabetic patients and demonstrated inverse association between ABCA1 gene expression and fasting glucose concentration [21]. However, an association between basal ABCA1 expression of PBMNCs and HDL-C levels in healthy individuals with low HDL-C has not been explored. The present study was therefore designed to analyse the basal ABCA1 gene expression of PBMNCs of healthy individuals with low HDL-C and compare with healthy individuals normal HDL-C as per NCEP [2001] criteria (18). Screening of healthy subjects was done very carefully through rigorous protocol involving fasting lipid profile, ECG and Carotid Doppler, to find any atherosclerotic symptoms. Subjects of any group were excluded if had triglycerides $>200 \mathrm{mg} /$ $\mathrm{dl}$ or were prescribed any hypolidemic drugs or suffering from any other disease.

Table 1: Demographic Data.

\begin{tabular}{|c|c|c|}
\hline Parameters & $\begin{array}{l}\text { Group 1 } \\
{[\mathrm{N}=27]}\end{array}$ & $\begin{array}{c}\text { Group } 2 \\
{[\mathrm{~N}=28]}\end{array}$ \\
\hline Male: Female & $17: 10$ & $22: 06$ \\
\hline Age [Years] & $45.8 \pm 12.8$ & $40.1 \mathrm{NS} \pm 9.96$ \\
\hline Body Mass Index (BMI) $\left[\mathrm{kg} / \mathrm{m}^{2}\right]$ & $24.2 \pm 3.67$ & $24.4 \mathrm{NS} \pm 3.89$ \\
\hline Waist : Hip & $0.89 \pm 0.06$ & $0.91 \mathrm{NS} \pm 0.06$ \\
\hline SBP [mmHg] & $121.9 \pm 8.2$ & $117.9 \mathrm{NS} \pm 7.1$ \\
\hline $\mathrm{DBP}[\mathrm{mmHg}]$ & $79.5 \pm 5.1$ & $77.2 \mathrm{NS} \pm 5.81$ \\
\hline Fasting Sugar $[\mathrm{mg} / \mathrm{dl}]$ & $98.4 \pm 18.0$ & $91.3 \mathrm{NS} \pm 8.00$ \\
\hline Total Cholesterol (TC) [mg/dl] & $188.2 \pm 28.0$ & $165.1^{* *} \pm 32.8$ \\
\hline HDL-Cholesterol (HDL-C) [mg/dl] & $46.6 \pm 10.1$ & $29.9^{* * *} \pm 4.01$ \\
\hline TC/HDL-C & $4.15 \pm 0.77$ & $5.57^{* * * \pm 1.10}$ \\
\hline Triglycerides [mg/dl] & $98.2 \pm 32.7$ & $112.8 \mathrm{NS} \pm 48.0$ \\
\hline $\begin{array}{l}\text { Very Low Density Lipoprotein - } \\
\text { Cholesterol (VLDL-C) [mg/dl] }\end{array}$ & $19.6 \pm 6.53$ & $22.6 \mathrm{NS} \pm 9.6$ \\
\hline $\begin{array}{l}\text { Low Density Lipoprotein - } \\
\text { Cholesterol (LDL-C) [mg/dl] }\end{array}$ & $122.0 \pm 23.2$ & $112.6 \mathrm{NS} \pm 30.3$ \\
\hline LDL-C/HDL-C & $2.71 \pm 0.68$ & $3.81^{* * *} \pm 1.05$ \\
\hline Apolipoprotein A1 (Apo A1) [g/L] & $1.15 \pm 0.25$ & $0.91^{* * *} \pm 0.15$ \\
\hline Apolipoprotein B (Apo B) [g/L] & $1.05 \pm 0.24$ & $1.03 \mathrm{NS} \pm 0.28$ \\
\hline ApoB/ApoA1 & $0.94 \pm 0.28$ & $1.15^{*} \pm 0.32$ \\
\hline
\end{tabular}

${ }^{* * *} \mathrm{p}<0.001,{ }^{* *} \mathrm{p}<0.01,{ }^{*} \mathrm{p}<0.05$, NS-Non-significant

Table 2: ABCA1 Gene and Protein Expression.

\begin{tabular}{|c|c|c|}
\hline Parameters & $\begin{array}{c}\text { Group 1 } \\
\text { [N=27] }\end{array}$ & $\begin{array}{c}\text { Group 2 } \\
\text { [N=28] }\end{array}$ \\
\hline $\begin{array}{c}\text { Relative ABCA1 Expression } \\
2^{\text {-delta delta Ct }}\end{array}$ & 1 & $\begin{array}{c}1.65 \\
(0.73 / 3.07) \\
(65.0 \%)\end{array}$ \\
\hline $\begin{array}{c}\text { ABCA1 Protein Expression } \\
\text { [OD at 450nm of 50 } \mu \mathrm{g} / \mathrm{ml} \\
\text { of total cell protein extract] }\end{array}$ & $0.80 \pm 0.09$ & $\begin{array}{c}0.66^{* * *} \pm 0.11 \\
\left(17.5 \%^{-}\right)\end{array}$ \\
\hline
\end{tabular}

${ }^{* * *} \mathrm{p}<0.001,{ }^{* *} \mathrm{p}<0.01,{ }^{*} \mathrm{p}<0.05$, NS-Non-significant 


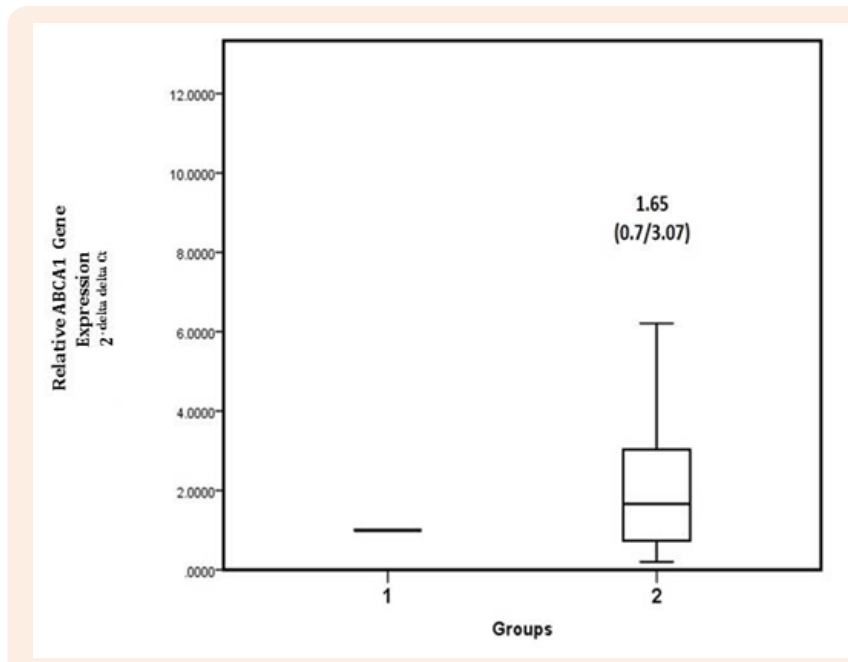

Figure 1: ABCA1 Gene Expression.

ABCA1 controls the first step of RCT which is rate-limiting step in HDL particle formation i.e. efflux of intracellular cholesterol to ApoA1 from peripheral cells. In the present study, expression of ABCA1 gene was increased in healthy individuals with low HDL-C while ABCA1 protein was decreased significantly as compared to controls. Thus increase in ABCA1 gene expression was not translated into increase in protein content and ABCA1 protein levels of individuals with low HDL-C levels did not increase proportionate to that of healthy individuals. Similar finding has been reported by Albrecht et al in their study on ABCA1 gene and protein expression in atherosclerotic tissues [22]. They have demonstrated that despite significant up-regulation of ABCA1 mRNA, ABCA1 protein was markedly reduced in advanced carotid atherosclerotic lesions showing discordance between ABCA1 gene and protein expression [22]. However, they have reported no differences in leukocyte ABCA1 mRNA expression of patients with atherosclerosis as compared to controls [22]. Similar finding has been reported in AMI patients with and without type 2 diabetes [19]. While Deminia et al (2011) have demonstrated decreased ABCA1 mRNA expression of PBMNCs in patients with atherosclerosis [23]. However, mRNA levels do not necessarily reflect protein expression. In the present study, in healthy subjects with low HDL-C, rise in ABCA1 gene expression in PBMNCs suggests an effort by cells to compensate ABCA1 transcript but it was not converted into protein levels.

\section{Conclusion}

ABCA1 controls the rate-limiting step in HDL particle formation and is therefore an attractive molecular target for raising HDL-C levels and as protection against atherosclerosis. In the present study up-regulation of ABCA1 protein failed to translate into ABCA1 protein. This implies that pharmacological targeting of ABCA1 gene expression pathway may not achieve the anticipated atherosclerotic protective effect and suggests some defect at translational and post translational level which needs to be further explored.

\section{Acknowledgement}

The authors acknowledge Sir H. N. Medical Research Society for financial support. Sir H. N. Hospital and Research Centre, Mumbai, and Rajawadi Hospital, Mumbai, for enrolling the patients in our study. Authors express sincere gratitude towards Reliance Life Sciences Centre, Navi Mumbai, for their permission to use Real Time PCR System. We gratefully acknowledge Ms. Anika Seth, Reliance Life Sciences, Navi Mumbai for her technical expertise.

\section{Conflict of Interest}

There were no financial interest or conflict of interest.

\section{References}

1. Fielding CJ, Fielding PE (1997) Intracellular cholesterol transport. J Lipid Res 38(8): 1503-1521.

2. Fielding CJ, Fielding PE (1995) Molecular physiology of reverse cholesterol transport. J Lipid Res 36(2): 211-228.

3. Schmitz G, Kaminski WE, Porsch OM, Klucken J, Orso E, et al. (1999) ATP-binding cassette transporter A1 (ABCA1) in macrophages: a dual function in inflammation and lipid metabolism? Pathobiology 67(5-6): 236-240.

4. Aiello RJ, Brees D, Francone OL (2003) ABCA1-deficient mice: insights into the role of monocyte lipid efflux in HDL formation and inflammation. Arterioscler Thromb Vasc Biol 23(6): 972-980.

5. Langmann T, Klucken J, Reil M, Liebisch G, Luciani MF, et al. (1999) Molecular cloning of the human ATP-binding cassette transporter 1 (hABC1): evidence for sterol-dependent regulation in macrophages. Biochem Biophys Res Commun 257(1): 29-33.

6. Bodzioch M, Orso E, Klucken J, Langmann T, Bottcher A, et al (1999). The gene encoding ATP binding cassette transporter 1 is mutated in Tangier disease. Nat Genet 22(4): 347-351.

7. Brooks Wilson A, Marcil M, Clee SM, Zhang LH, Roomp K, et al. (1999) Mutations in ABC1 in Tangier disease and familial high-density lipoprotein deficiency. Nat Genet 22(4): 336-345.

8. Rust S, Rosier M, Funke H, Real J, Amoura Z, et al. (1999) Tangier disease is caused by mutations in the gene encoding ATP-binding cassette transporter 1. Nat Genet 22(4): 352-355.

9. Oram JF, Heinecke JW (2005) ATP-binding cassette transporter A1: A cell cholesterol exporter that protects against cardiovascular disease. Physiol Rev 85(4): 1343-1372.

10. Singaraja RR, Bocher V, James ER, Clee SM, Zhang LH, et al. (2001) Human ABCA1 BAC transgenic mice show increased high density lipoprotein cholesterol and ApoAI-dependent efflux stimulated by an internal promoter containing liver $\mathrm{X}$ receptor response elements in intron 1. J Biol Chem 276(36): 33969-33979.

11. Aiello RJ, Brees D, Bourassa PA, Royer L, Lindsey S, et al. (2002) Increased atherosclerosis in hyperlipidemic mice with inactivation of ABCA1 in macrophages. Arterioscler Thromb Vasc Biol 22(4): 630-637.

12. Van Eck M, Bos IS, Kaminski WE, Orso E, Rothe G, et al. (2002) Leukocyte ABCA1controls susceptibility to atherosclerosis and macrophage recruitment into tissues. Proc Natl Acad Sci 99(9): 6298-6303. 
13. Mineo C, Deguchi H, Griffin JH, Shaul PW (2006) Endothelial and antithrombotic actions of HDL. Circ Res 98(11): 1352-1364.

14. Barter PJ (2005) Cardioprotective effects of high-density lipoproteins the evidence strengthens. Arterioscler Thromb Vasc Biol 25(7): 1305-1306.

15. Goldbourt U, Yaari S, Medalie JH (1997) Isolated low HDL cholesterol as a risk factor for coronary heart disease mortality: A 21-year follow up of 8000 men. Arterioscler Thromb Vasc Biol 17(1): 107-113.

16. Weverling-Rijnsburger AW, Jonkers IJ, Van Exel E, Gussekloo J, Westendorp RG (2003) High density vs. low-density lipoprotein cholesterol as the risk factor for coronary artery disease and stroke in old age. Arch Intern Med 163(13): 1549-1554.

17. Miller M, Rhyne J, Hamlette S, Birnbaum J, Rodriguez A (2003) Genetics of HDL regulation in humans. Curr Opin Lipidol 14(3): 273279.

18. Expert Panel on Detection, Evaluation and Treatment of High Blood Cholesterol in Adults (2001) Executive Summary of The Third Report of The National Cholesterol Education Program (NCEP) Expert Pane on Detection, Evaluation, And Treatment of High Blood Cholesterol In Adults (Adult Treatment Panel III). JAMA 285(19): 2486-2497.
19. Shalia KK, Saranath D, Shah VK (2015) Peripheral Blood Mononuclear Cell ABCA1 Transcripts and Protein Expression in Acute Myocardial Infarction. J Clin Lab Anal 29(3): 242-249.

20. Guan JZ, Tamasawa N, Murakami H, Matsui J, Tanabe J, et al. (2008) HMG-CoA reductase inhibitor, simvastatin improves reverse cholesterol transport in type 2 diabetic patients with hyperlipidemia. J Atheroscler Thromb 15(1): 20-25.

21. Albrecht C, Simon VI, Elliott JI, Higgins CF, Johnston DG, et al. (2004) Leukocyte ABCA1 gene expression is associated with fasting glucose concentration in normoglycemic men. Metabolism 53(1): 17-21.

22. Albrecht C, Soumian S, Amey JS, Sardini A, Higgins CF, et al. (2004) ABCA1 expression in carotid atherosclerotic plaques. Stroke 35(12): 2801-2806.

23. Demina EP, Miroshnikova VV, Rodygina TI, Kurianov PS, Vinogradov AG, et al. (2011) ABCA1 gene expression in peripheral blood lymphocytes and macrophages in patients with atherosclerosis. Mol Biol (Mosk) 45(2): 289-293. 